\title{
The Designing of Adaptive Self-Assessment Activities in Second Language Learning using Massive Open Online Courses (MOOCs)
}

\author{
Hasmaini Hashim ${ }^{1}$, Sazilah Salam ${ }^{2}$, Siti Nurul Mahfuzah Mohamad ${ }^{3}$, Nur Syafiatun Safwana Sazali ${ }^{4}$ \\ Fakulti Teknologi Maklumat dan Komunikasi \\ Universiti Teknikal Malaysia Melaka \\ Melaka, Malaysia
}

\begin{abstract}
Massive Open Online Courses (MOOCs) provides an effective learning platform with various high-quality educational materials accessible to learners from all over the world. In this paper, the types of learner characteristics in MOOCs second language learning are discussed. However, there are still problems and challenges including assessment. A quantitative research method approach has been utilized in this study. Results of the study are then used for implementing suitable adaptive self-assessment activities in MOOCs learning. Findings of this study are two folds: (1) The dimension of learner characteristics (learning styles and cognitive style) for improving student performance in MOOCs learning and (2) suitable selfassessment activities that consider learners requirement or adaptive to learner characteristics for improving MOOCs learning performance. Based on the findings, the data indicate that visual, active, thinking and intuitive learner is the proposed dimension used in this study. In this study, our aim is to propose adaptive self-assessment activities for improving MOOCs learning in the second language course. In the future study, students will be investigated about their engagement using MOOC assessment in the second language.
\end{abstract}

Keywords-MOOCs; adaptive self-assessment; learning styles; cognitive styles; second language

\section{INTRODUCTION}

Massively Open Online Courses (MOOCs) have the potential to reach hundreds of thousands of learners enrolled for a variety of reasons [1]. Authors highlighted three controversies for learning in MOOCs in for higher education; (1) measurement, (2) assessment and (3) accountability. Wong [2] highlighted that in MOOC assessment is a big challenge for a large number of students to get detailed and timely feedback. However, the assessment can increase the student performance and at the same time, the teacher brings benefits [3]. Current MOOCs are (1) lacking personalized to learning guidance and (2) intelligent assessment for learners [4]. In MOOC assessment, the issue is, there was a reduction of interest and activity of students during the session of the course [5]. Three requirements to designing effective online course are (1) learners characteristics, (2) context and (3) activities [6]. These authors suggest a reconceptualization of (1) curriculum activities and (2) student achievement based in various indicators of performance. The previous researcher mentioned that assessment is an important part to test and control the learning process of learners [7]. The author stated that in adaptive learning, the suitable adaptive assessment methods are needed to provide the learners with a consistent learning process.

This study aimed to propose adaptive self-assessment activities for improving Massive Open Online Courses (MOOCs) learning performance in the second language and the research questions (RQ) were constructed as follows:

RQ 1: What are the learning styles of learners that used the second language in MOOCs learning?

RQ 2: What are the cognitive styles of learners that used the second language in MOOCs learning?

RQ 3: What are the suitable adaptive self-assessment activities element designs for the student in second language MOOCs learning?

This paper is organized as follows: Section II is a literature review. Section III describes the methodology and method. In Section IV, we review the results, discuss the designs and propose an adaptive self-assessment based on elements of learner characteristics in MOOC assessment. Finally, Section $\mathrm{V}$ gives a conclusion of the main finding in this paper.

\section{LITERATURE REVIEW}

Learner characteristics are important in all forms of online learning [8]. Most researchers focused predominantly on user perception of MOOC features, rather than individual learner characteristics such as exploring the factors which affect MOOC completion or learner retention [9]. However, Judy and Jean [10] listed three types of learner characteristics that are effective factors for student learning: (1) learning style, (2) cognitive style and (3) multiple intelligence.

\section{A. Learning Styles}

According to Ali [11], learning styles are the ways of receiving and responding to a learning stimulus with (1) unique psychological, (2) affective and (3) cognitive composition. Learning styles refer to the variations in an individual's ability to accumulate and assimilate information, sensory preferences that have the impact on learning and related to personality [10], [11], [12]. Previous researchers mentioned that learning styles refer to the way learners receive and perceive the information [13]. Learning styles are authentic as they are the appropriate techniques or methods in which learners learn, comprehend and get information [14]. 
TABLE I. ELEMENTS FOR THE DIMENSION OF LEARNING STYLES

\begin{tabular}{|c|c|c|c|c|c|c|}
\hline \multirow{3}{*}{ 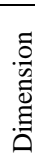 } & \multirow[t]{3}{*}{ Element } & \multicolumn{5}{|c|}{ Author } \\
\hline & & {$[14]$} & [13] & {$[15]$} & [16] & [17] \\
\hline & & & & & & \\
\hline & Learn by trying things & & & $\mathrm{X}$ & & \\
\hline & Can be impulsive & $\mathrm{X}$ & & & & \\
\hline & Risk-takers & $\mathrm{X}$ & & & & \\
\hline.$\geq$ & Do not prefer lectures & $\mathrm{X}$ & & & & \\
\hline 过 & Interpersonal & $\mathrm{X}$ & & & & \\
\hline & Prefer group work & $\bar{X}$ & $\mathrm{X}$ & $\mathrm{X}$ & $\mathrm{X}$ & $\mathrm{X}$ \\
\hline & $\begin{array}{c}\text { Participate in learning tasks } \\
\text { immediately }\end{array}$ & & & & $\mathrm{X}$ & $\mathrm{X}$ \\
\hline & $\begin{array}{c}\text { Think about concepts before } \\
\text { action }\end{array}$ & $\mathrm{X}$ & & & & \\
\hline & $\begin{array}{l}\text { Like writing } \\
\end{array}$ & $\mathrm{X}$ & & & & \\
\hline 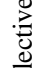 & $\begin{array}{l}\text { Not inclined to too much } \\
\text { note-taking }\end{array}$ & $\mathrm{X}$ & & & & \\
\hline प्ञ & Learn by thinking & $\mathrm{X}$ & $\mathrm{X}$ & $\mathrm{X}$ & & \\
\hline & Intrapersonal \& introspective & $\mathrm{X}$ & & & & \\
\hline & Adopt analytical approach & & & & $\mathrm{X}$ & $\mathrm{X}$ \\
\hline & Working alone & & $\mathrm{X}$ & $\mathrm{X}$ & $\mathrm{X}$ & $\mathrm{X}$ \\
\hline & Learn from concrete material & $\mathrm{X}$ & $\mathrm{X}$ & $\mathrm{X}$ & & \\
\hline. & Prefer facts & & & & $\mathrm{X}$ & $\mathrm{X}$ \\
\hline$\tilde{ల}$ & $\begin{array}{l}\text { Follow tutors' approaches in } \\
\text { problem-solving }\end{array}$ & & & & $\mathrm{X}$ & $\mathrm{X}$ \\
\hline$\stackrel{0}{\geq}$ & $\begin{array}{c}\text { Prefer to learn abstract } \\
\text { material. }\end{array}$ & $\mathrm{X}$ & $\mathrm{X}$ & $\mathrm{X}$ & $\mathrm{X}$ & $\mathrm{X}$ \\
\hline 菲 & $\begin{array}{l}\text { Learn and tend to apply their } \\
\text { own innovation }\end{array}$ & & & & $\mathrm{X}$ & $\mathrm{X}$ \\
\hline בू & $\begin{array}{l}\text { Learn best from what they } \\
\text { see }\end{array}$ & & & $\mathrm{X}$ & & \\
\hline$\stackrel{2}{>}$ & Prefer pictorial materials & $\mathrm{X}$ & $\mathrm{X}$ & & $\mathrm{X}$ & $\mathrm{X}$ \\
\hline & Prefer to learn from words & $\mathrm{X}$ & $\mathrm{X}$ & $\mathrm{X}$ & & \\
\hline 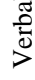 & Prefer written and listen & & & & $\mathrm{X}$ & $\mathrm{X}$ \\
\hline & Prefer step in a linear way & & & $\mathrm{X}$ & $\mathrm{X}$ & $\mathrm{X}$ \\
\hline 苂 & Logically sequenced steps & $\mathrm{X}$ & & & & \\
\hline $\bar{\Xi}$ & Focus on details & & & & & $\mathrm{X}$ \\
\hline$\overline{\mathscr{D}}$ & $\begin{array}{c}\text { Learn in continual small } \\
\text { steps }\end{array}$ & & $\mathrm{X}$ & & & \\
\hline ర్ & $\begin{array}{c}\text { Prefer to learn in large leaps, } \\
\text { skipping, understand and } \\
\text { look at detail }\end{array}$ & & & $\mathrm{X}$ & $\mathrm{X}$ & $\mathrm{X}$ \\
\hline $\bar{J}$ & $\begin{array}{l}\text { Learn holistically in large } \\
\text { jumps }\end{array}$ & $\mathrm{X}$ & $\mathrm{X}$ & & & \\
\hline
\end{tabular}

As mentioned by Mohamad [18], each student has his or her own learning style to be considered during the learning process. Ali [11] listed three important elements for learning styles: (1) academic achievements, (2) attitudes towards learning and (3) multimedia technology. Sadhasivam and Babu [14] listed a few learning style models to build up their pedagogical hypothesis: (1) Kolb Experiential Learning Theory; (2) VARK Model, (3) Felder \& Silverman Learning/Teaching Style Model and 4) Dunn and Dunn Learning Style Mode. The previous researcher mentioned that the most appropriate model for open learning is Felder and Silverman Learning Style Model [13].

Previous studies have found four different dimensions of learning styles: (1) processing (active/reflective), (2) perception (sensory/intuitive), (3) input (visual/verbal) and (4) understand (sequential/global) [13], [19], [15]. Rohaniyah [20] stated the major differences in learning styles are the (1) the way a people perceive (sensation versus intuition), (2) the way they made a decision (logical thinking versus imaginative feelings) and (3) how active or reflective for interacting (extroversion versus introversion). Table I shows elements for the dimension of learning styles. Researchers highlighted that there is a lack of studies investigating how learning styles affect to the students' reactions in the context of assessment [21]. This finding shows visual learning styles was the control item and suggested making use of different learning styles as an independent variable.

\section{B. Cognitive Styles}

TABLE II. ELEMENTS FOR THE DiMENSION OF COGNITIVE STYLES

\begin{tabular}{|c|c|c|c|c|}
\hline \multirow[b]{2}{*}{ 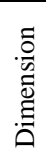 } & \multirow[t]{2}{*}{ Elements } & \multicolumn{3}{|c|}{ Author } \\
\hline & & [10] & [22] & [23] \\
\hline \multirow{3}{*}{ 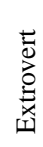 } & Outer world & $\mathrm{X}$ & & $\mathrm{X}$ \\
\hline & Collaborate with others & & $\mathrm{X}$ & \\
\hline & Try things out for himself & & & $\mathrm{X}$ \\
\hline \multirow{3}{*}{ 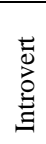 } & Inner world & $\mathrm{X}$ & & $\mathrm{X}$ \\
\hline & Independent & & $\mathrm{X}$ & $\mathrm{X}$ \\
\hline & Reflect on thoughts and ideas & & & $\mathrm{X}$ \\
\hline \multirow{3}{*}{ 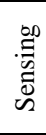 } & Real objects and solid facts. & $\mathrm{X}$ & & $\mathrm{X}$ \\
\hline & $\begin{array}{l}\text { Physical qualities and affection by other } \\
\text { information }\end{array}$ & & $\mathrm{X}$ & \\
\hline & Rely on past experiences & & & $\mathrm{X}$ \\
\hline \multirow{3}{*}{$\begin{array}{l}\text { 叴 } \\
\text { 总 }\end{array}$} & Possibilities and personal meaning & $\mathrm{X}$ & & \\
\hline & Intuitive types & & $\mathrm{X}$ & \\
\hline & Speculations & & & $\mathrm{X}$ \\
\hline \multirow{3}{*}{ 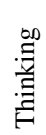 } & Analyzing fact & $\mathrm{X}$ & & $\mathrm{X}$ \\
\hline & Structure and function & & $\mathrm{X}$ & \\
\hline & Logical and rational decisions & & & $\mathrm{X}$ \\
\hline \multirow{3}{*}{ 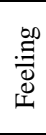 } & Subjective values and views & $\mathrm{X}$ & & $\mathrm{X}$ \\
\hline & Initial energetic condition and interactions & & $\mathrm{X}$ & \\
\hline & $\begin{array}{l}\text { Decisions based on the people and their } \\
\text { actions }\end{array}$ & & & $\mathrm{X}$ \\
\hline \multirow{6}{*}{ 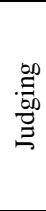 } & Planned & $\mathrm{X}$ & & \\
\hline & Organized way & $\mathrm{X}$ & $\mathrm{X}$ & $\mathrm{X}$ \\
\hline & Prefers control & $\mathrm{X}$ & & \\
\hline & Seek closure & & $\mathrm{X}$ & \\
\hline & Think sequentially & & $\mathrm{X}$ & \\
\hline & Orderly & & & $\mathrm{X}$ \\
\hline \multirow{3}{*}{ 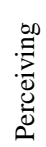 } & Flexible & $\mathrm{X}$ & $\mathrm{X}$ & $\mathrm{X}$ \\
\hline & Spontaneous way of life & $\mathrm{X}$ & & $\mathrm{X}$ \\
\hline & To keep things open ended & & $\mathrm{X}$ & \\
\hline
\end{tabular}

Previous research listed five definition for cognitive styles, namely (1) the way people think, (2) the accuracy of their perception, (3) how they process and remember information, (4) how they use the information in problem-solving or (5) how they organize and process information [18] and [19]. The 
previous study listed three parts of cognitive style: (1) an individual's stability, (2) characteristic of the mental approach, or (3) cognitive preferences [20]. The author has proposed three elements of the cognitive style dimension: (1) processing information, (2) solving problems and (3) making decisions.

Cognitive styles are preferences or strategies used by individuals that influence functions such as (1) perceiving, (2) remembering, (3) thinking and (4) problem solving [24]. Previous researcher has used a cognitive style questionnaire proposed by Ancona [25], and the cognitive style dimensions are: (1) energy (extroversion/introversion), (2) information (sensing/ intuitive), (3) decisions (thinking/feeling) and (4) lifestyle (judging/perceiving) [26]. Researchers conclude that the student's cognitive style impacts their performance via eactivities. Therefore, in this study, we focus this questionnaire to investigate the type of learner dimension for the student using MOOCs learning and proposed the suitable selfassessment activities. Table II shows elements for the dimension of cognitive styles.

\section{Assessment}

MOOC in education must have three requirements; (1) assessment (2) instructor and (3) model [27]. The researchers list two factors caused a lack of assessment to student achieved learning outcomes in higher education, which are (1) limitation of experiential learning and (2) many high-impact practices [28]. Gikandi et. al. [29] stated the term of assessment refer to the measurement of the learner's achievement and progress in a learning process. Two major types of assessment exist, which are (1) formative and (2) summative assessments. Formative assessment refers to the continuing feedback aiming to advance teaching and learning [30], while summative assessments, on the others hands refers to measure students' learning progress at the end of learning [31]. Previous researchers stated that the quality of both assessments was moderate [32]. In MOOC assessment, the issue is, there was a reduction of interest and activity of students during the session of the course [5].

Chan and King [33] mentioned, one of the most challenging problems in MOOCs is that it is infeasible for the teaching staffs to grade all the assignments on such a large scale. The design of engaging and challenging assessment tasks is one of the most important elements of planning a course [34]. The is a limitation of experiential learning and many high-impact practices in higher education are lacking assessment for embedded learning outcomes at the individual learner level [28]. Based on the previous study, in an attempt to avoid focusing on a broad assessment issue in of MOOC as a phenomenon, the researchers limited each case study by time and course design and activities [1]. Authors listed that common activities amongst all courses were: (1) Video lectures, (2) demonstrations, (3) discussion forums, (4) quizzes, (5) projects, (6) PowerPoint slides, (7) reading the material and (8) online learning resources. In this study, researchers focus on five types of activities designed: (1) quiz, (2) listening assessment, (3) forum, (4) mid-term test and (5) project.

\begin{tabular}{|c|c|c|c|c|c|}
\hline $\begin{array}{l}\text { Assessment features/MOOC } \\
\text { Platform }\end{array}$ & edX & coursera & miriada & mowecosor & Oopenteming \\
\hline Hints, a daptive exercises, etc. & & - & - & & \\
\hline $\begin{array}{l}\text { Automatic correction of exercises } \\
\text { with artificial intelligence }\end{array}$ & & - & - & & \\
\hline Interactive exercises & & & & & \\
\hline Peer review & & & & & \\
\hline Gamification & & - & - & & \\
\hline $\begin{array}{l}\text { Adaptation of the leaming process } \\
\text { and recommendations }\end{array}$ & & - & - & & \\
\hline $\begin{array}{l}\text { Authoring tools for complex } \\
\text { assessment a ctivities }\end{array}$ & & - & - & - & \\
\hline Leaming analytics & & & & & \\
\hline Social interaction functionality & & & & & \\
\hline $\begin{array}{l}\text { Setting students own leaming } \\
\text { objectives and goals }\end{array}$ & - & - & - & $\zeta$ & - \\
\hline
\end{tabular}

Fig. 1. Comparison of the assessment functionality for MOOCs

All of the MOOC platforms can greatly improve the automatic correction of exercises using artificial intelligence techniques, the adaptation of assessment activities or the gamification features, although some platforms have already done some initial steps in these directions. The challenges when applying these online assessment methods are (1) student's engagement and (2) motivation to complete the eactivities. The researcher suggested two requirements to improved assessment in MOOC platform (1) new developments must make a perfect solution for assessment and (2) need to improve in the different aspects and features [35]. Fig. 1 shows the comparison of the assessment functionality for MOOCs between popular MOOC platforms.

Taras [36] also highlighted that self-assessment has been shown to support student learning. The author mentioned that the term 'self-assessment' is used to cover all judgments by learners of their work which subsumes terms such as (1) 'selfevaluation' and (2) 'self-appraisal'. However, models used for adaptive assessment have been mostly summative: they measure or rank effectively examinees, but do not provide any other feedback [37]. Gohokar [38] listed three requirements for improving learning performance of the course (1) adaptive, (2) innovative and cognitive tools and (3) techniques. In an assessment, adaptive can lead to improved personalization, by organizing learning resources [37]. The authors mentioned adaptive assessment is more and more useful in the current age of MOOCs, where motivation plays an important role. In this study, the aim is to propose adaptive self-assessment activities in MOOCs learning in the second language course based on learner characteristics to improving student performance.

\section{MATERIALS AND METHODS}

This part described the research methodology and the research design of this study. This part also addressed aspects of research design such as theoretical framework and proposed assessment activities. 


\section{A. Questionnaire}

The questionnaire consists of 2 part and 24 survey items measuring the different types of learner characteristics and 50 students participated as the respondents for the study. The survey items were adapted from several research projects with similar research scope [25] and [39]. The questionnaires were distributed and instructions were given to the respondents. Participation was voluntary. All participants were given the survey via by hand.

\section{B. Research Instrument}

There are many ways to determine learner styles strengths dimension. The survey items were adapted from several research projects with similar research scope [25] and [39] had been created for this purpose. Questionnaire method was used as the research instrument in this study. This questionnaire is used to determine which learning styles and cognitive styles dimension are the strongest for technical student. Once the items of the survey instrument were scored, the points for each of the learning styles and cognitive styles dimension were totaled for each student using the Ms. Excel.

\section{Theoretical Framework}

Fig. 2 illustrated the theoretical framework of this paper. Exclusively, the theoretical framework defined the learner characteristics as the independent variable and dependent variable are student performance. The learner characteristics consist of two construct: (1) learning styles and (2) cognitive styles. The student performance are measured the mark for each MOOC assessment such as mid-term test.

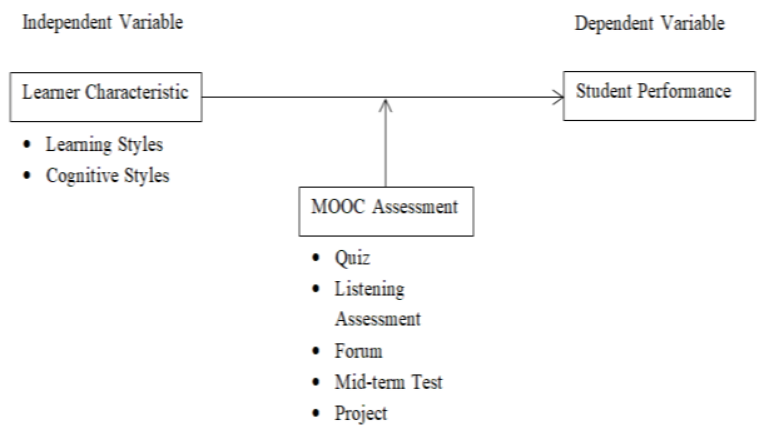

Fig. 2. The theoretical framework

\section{RESULTS AND DISCUSSION}

In this part, the results of data analysis are presented from both methods. The findings are presented, analyzed and discussed based on the research question.

\section{A. Research Question 1: What are the Learning Styles of Learners that used Second Language in MOOCs Learning?}

The findings of the questionnaires indicated visual as the highest percentage of learning styles for students based on the Felder and Silverman Learning Style Model in Mandarin MOOC. According to the results of the learning styles questionnaire, Fig. 3 shows the dimension of learning styles by percentages in MOOCs learning. Visual and active learner dimension has the highest percentage, values of $76.00 \%$ and $74 \%$, respectively.

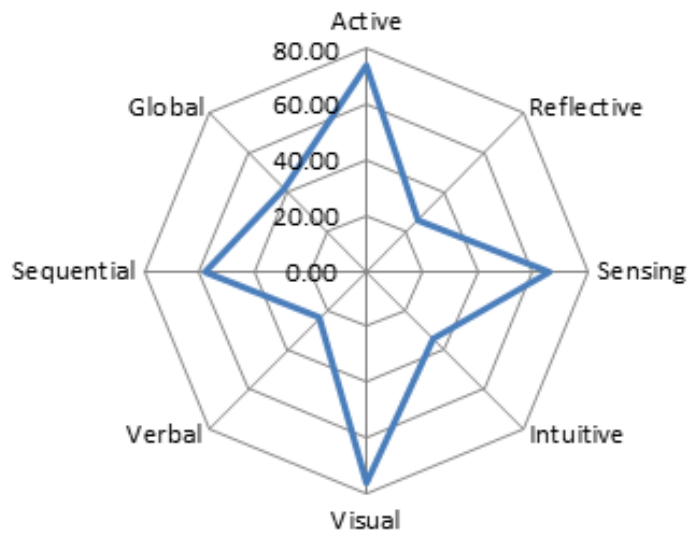

Fig. 3. Dimensions of learning styles

The previous researcher stated that the stronger the visual style of learning was, the more time the learners spent on pictorial content [24]. Most researchers mentioned that visual learners outperformed verbal learners such as focused on pictorial learning objects and learn best from what they see [15] and [24]. Visual learners almost prefer video, demonstrations, pictures and graphs [19]. The visual persons like to receive information through pictures and diagrams [40], [41]. Therefore these learners prefer the use of pictures, imageries and spatial perception [40]. Zhong [42] stated that online students are mostly visual learners while the traditional student are mostly auditory or kinesthetic learners. For example, almost all students from Asian cultures are highly visual learner [40].

Active learners are defined the as learners who prefer to process information actively by doing something with the learned material, for example discussing, explaining or testing [43]. Active learners acquire knowledge best by trying things out and working with others in groups [41]. Active learners prefer studying in groups, immediately doing learning tasks, working with others, learn by doing something with information and they prefer to process information by talking about it and trying it out [13], [14], [17]. The previous researcher found that active learners possessed significantly higher intention towards an interactive learning technology (wiki) than the reflective group [17]. However, active learners did not like to be passive participants in educational activities. The researcher listed two requirements needed to support student engagement and guide the student to become an active learner, namely: (1) course tools and (2) media [44].

Based on the literature review, two elements in the visual learner dimension were identified: (1) learn best from what they see, and (2) learners priorities pictorial materials. While seven elements in the active learner dimension were identified: (1) learn by trying things, (2) can be impulsive, (3) risk-takers, (4) do not prefer lectures, (5) interpersonal, (6) prefer group work and (7) participate in learning tasks immediately. Based on findings from RQ1, the researchers proposed an existing element learning styles (visual and active) in adaptive self-assessment activities for improving student performance using MOOCs learning for the second language course. 


\section{B. Research Question 2: What are the Cognitive Styles of Learners that used Second Language in MOOCs Learning?}

Based on the results of the learner characteristics questionnaire, the dimension of cognitive style by percentages in MOOCs learning is shown in Fig. 4 below. Thinking and intuitive learner dimension have the highest percentage, values of $70.00 \%$ and $64 \%$, respectively. Ghaedi and Bashir [45], mentioned thinking learner tends to complete their work in an organized and efficient manner. Intuitive learners often prefer discovering possibilities and relationships [46].

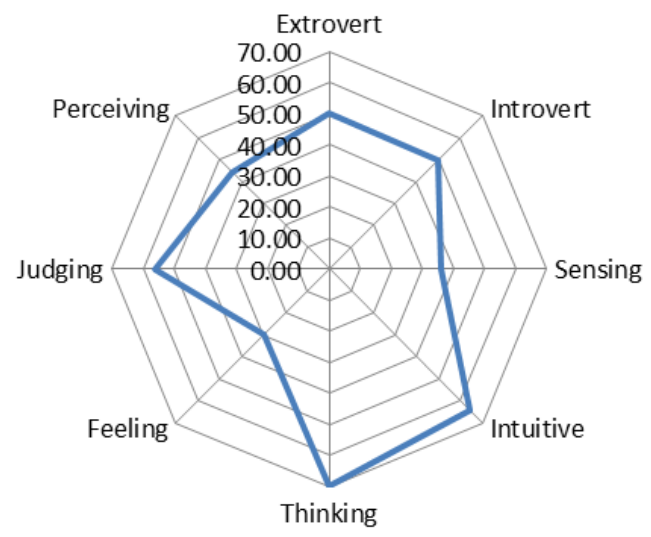

Fig. 4. Dimensions of cognitive styles

Based on the literature review, three elements in the thinking style were identified: (1) analyzing fact, (2) structure and function and (3) logical and rational decisions. While three elements in the active learner dimension were also identified: (1) possibilities and personal meaning, (2) intuitive types and (3) speculations. Based on findings from RQ2, the researchers proposed an existing element cognitive style (thinking and intuitive) in adaptive self-assessment activities for improving student performance using MOOCs learning for the second language course.

\section{Research Question 3: What are the Suitable Adaptive self- Assessment Activities Element Designs for the Student in Second Language MOOCs Learning?}

To answer RQ3, the researchers focused on designing MOOC self-assessment activities for two selected dimensions of learning styles and two selected dimensions of cognitive styles. Based on the findings, the data indicate that visual, active, thinking and intuitive learner is the highest dimension for both learner characteristics. Once the dimensions have been determined, the MOOC topic learning outcomes were used as guidance in selecting which types of MOOC selfassessment activities can be incorporated with which learning styles and cognitive styles dimensions. Table III shows the dimensions of both styles that can be adapted into potential MOOC self-assessment activities to improve student performance in MOOCs learning. In this table, the design of a question for this self-assessment activity (e.g. Quiz) will use the dimension of learning styles (e.g. Visual).
TABLE III. DIMENSIONS OF BOTH STYLES

\begin{tabular}{|c|c|c|}
\hline $\begin{array}{l}\text { Learner } \\
\text { Characteristics }\end{array}$ & Dimension & MOOC Self-Assessment Activities \\
\hline \multirow[t]{2}{*}{ Learning Styles } & Visual & $\begin{array}{l}\text { Quiz: Multiple Choice (MC), } \\
\text { True/False (T/F), Drag \& Drop, } \\
\text { Match }\end{array}$ \\
\hline & Active & \multirow{3}{*}{$\begin{array}{l}\text { Quiz: Multiple Choice (MC), } \\
\text { True/False (T/F), Drag \& Drop, } \\
\text { Match } \\
\text { Listening Assessment } \\
\text { Forum } \\
\text { Mid-Term Exam } \\
\text { Project: Writing, Presentation }\end{array}$} \\
\hline \multirow{2}{*}{$\begin{array}{l}\text { Cognitive } \\
\text { Styles }\end{array}$} & Thinking & \\
\hline & Intuitive & \\
\hline
\end{tabular}

Results of further analysis on each question/item in selfassessment activities for each element in learning styles and cognitive styles dimensions are presented in Table IV. In this table, a shaded box means that the design of a question for this self-assessment activity (e.g. T/F) will incorporate the element of its associated learning styles (e.g. Trying things).

TABLE IV. SELF-ASSESSMENT ACTIVITIES VERSUS ELEMENT OF DIMENSION IN MOOC PLATFORM

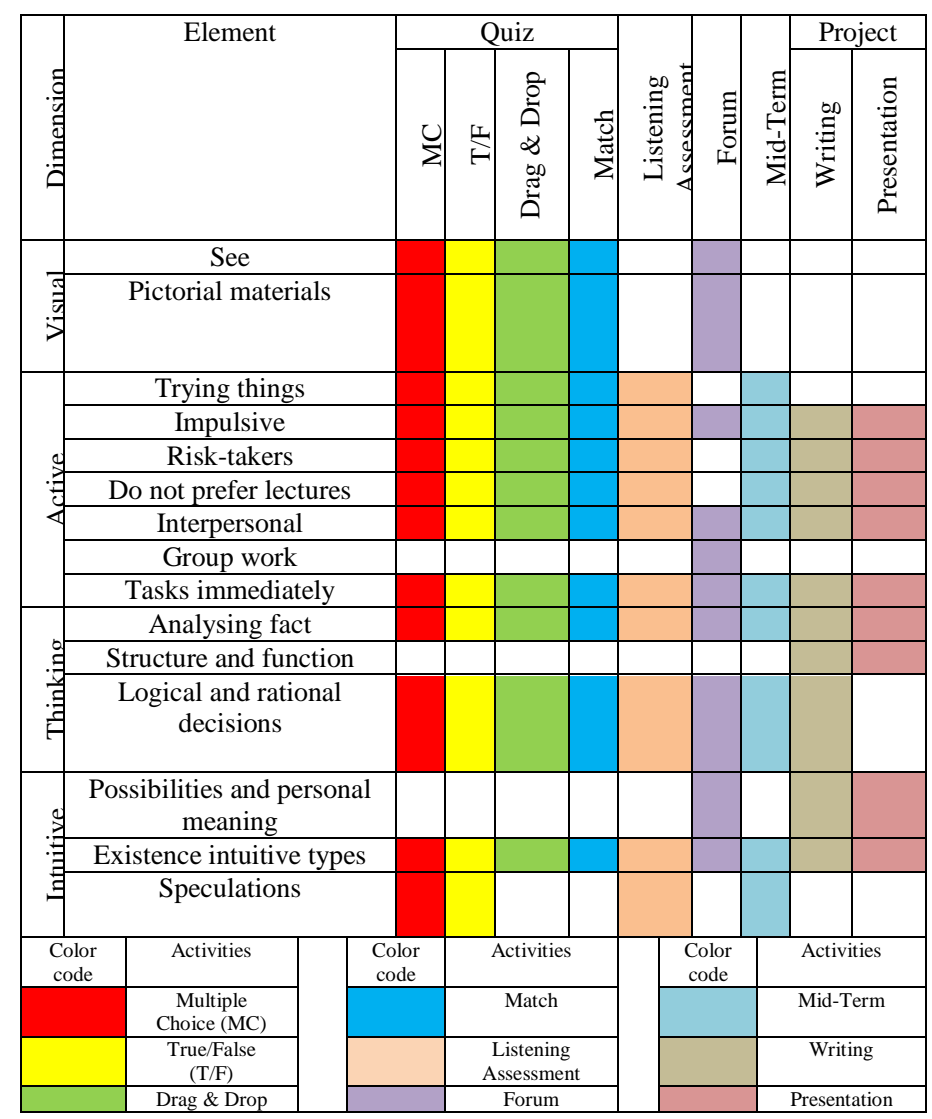

Visual learner dimensions divided by four of the adaptive self-assessment activities for MOOCs: (1) Multiple Choice (MC), (2) True/False (T/F), (3) Drag \& Drop and (4) Match. Meanwhile, active, thinking and intuitive learner dimensions divided by nine of the adaptive self-assessment activities for MOOCs: (1) Multiple Choice (MC), (2) True/False (T/F), (3) 
Drag \& Drop, (4) Match (5) Listening Assessment, (6) Forum, (7) Mid-Term, (8) Writing and (9) Presentation. Further analysis, the researchers focused on designing MOOC selfassessment activities using selected MOOC functional features that are suitable for a particular learner characteristic dimension such as hints and interactive. The design of a question for this self-assessment activity (e.g. MC) will incorporate the feature of its associated learner characteristic (e.g. 'Hints' in 'Graphics' form).

\section{CONCLUSION}

This initial study identified the learner characteristics of learners using MOOC assessment. The findings of the questionnaire indicated visual and active as the learner dimension for learning styles. While the learner dimension for cognitive styles is thinking and intuitive. The results from the percentage analysis revealed that out of the eight dimensions of learning styles, the preferred dimensions were visual and active learner $(76 \%$ and $74 \%)$. As for cognitive styles, the preferred dimensions were thinking and intuitive learner $(70 \%$ and 64\%). The suitable adaptive self-assessment activities design was also proposed for improving student performance in MOOCs learning for the second language course. In the future study, students will be investigated about their engagement using MOOC assessment in the second language course.

\section{ACKNOWLEDGMENT}

This research was conducted by the Pervasive Computing \& Educational Technology Research Group, C-ACT, Universiti Teknikal Malaysia Melaka (UTeM), and supported by the Ministry of Higher Education (MOE). FRGS grant: FRGS/1/2016/ICT01/FTMK-CACT/F00327.

\section{REFERENCES}

[1] A. Stanley and M A. Stanley and M. Moallem, "Assessment in MOOCs: A Comparative Analysis," in Proceedings of Society for Information Technology \& Teacher Education International Conference 2016, 2016, pp. 394-400.

[2] B. T. Wong, "Factors leading to effective teaching of MOOCs," Asian Assoc. Open Univ. J., vol. 11, no. 1, pp. 105-118, 2016.

[3] T. Tenório, I. I. Bittencourt, S. Isotani, and A. P. Silva, "Does peer assessment in on-line learning environments work? A systematic review of the literature," Comput. Human Behav., vol. 64, pp. 94-107, 2016.

[4] Z. Wang, "Structured Knowledge Tracing Models for Student Assessment on Coursera," in Proceedings of the Third (2016) ACM Conference on Learning @ Scale, 2016, pp. 209-212.

[5] L. S. Lisitsyna and A. E. Evgenii, "Making MOOCs More Effective and Adaptive on Basis of SAT and Game Mechanics," Smart Educ. eLearning 2017, Smart Innov. Syst. Technol. 75, vol. 75, 2017.

[6] O. Pilli and W. Admiraal, "Students' Learning Outcomes in Massive Open Online Courses (MOOCs): Some Suggestions for Course Design," J. Higher Educ., vol. 7, no. 1, pp. 46-71, 2017.

[7] F. E. Louhab, A. Bahnasse, and M. Talea, "Towards an Adaptive Formative Assessment in Context-Aware Mobile Learning," in Procedia Computer Science, 2018, vol. 135, pp. 441-448.

[8] Y. Park, I. Jung, and T. C. Reeves, "Learning from MOOCs: a qualitative case study from the learners' perspectives," EMI. Educ. Media Int., vol. 52, no. 2, pp. 72-87, 2015.

[9] K. S. Hone and G. R. El Said, "Exploring the factors affecting MOOC retention: A survey study," Comput. Educ., vol. 98, pp. 157-168, 2016.

[10] J. Lever-Duffy and J. B.McDonald, Teaching and Learning With Technology, 3rd ed. Boston: Pearson, 2009.
[11] R. Ali, "Learning Style Construct in Student's Learning," J. Indones. untuk Kaji. Pendidik., vol. 1(2), no. November, pp. 213-222, 2016.

[12] M. E. R. Abante, B. C. Almendral, J. E. Manansala, and J. Mañibo, "Learning Styles and Factors Affecting the Learning of General Engineering Students,” Int. J. Acad. Res. Progress. Educ. Dev., vol. 3, no. 1 , pp. 16-27, 2014.

[13] H. Fasihuddin, G. Skinner, and R. Athauda, "Towards adaptive open learning environments: Evaluating the precision of identifying learning styles by tracking learners' behaviours," Educ. Inf. Technol., vol. 22, no. 3, pp. 807-825, 2017.

[14] J. Sadhasivam and R. Babu, "MOOC : A Framework for Learners Using Learning Style," Int. Educ. Res. J., vol. 3, no. 2, pp. 21-24, 2017.

[15] B. Hmedna, A. El Mezouary, O. Baz, and D. Mammass, "A Machine Learning Approach to Identify and Track Learning Styles in MOOCs," in International Conference on Multimedia Computing and Systems (ICMCS'16), 2016.

[16] A. Al-Azawei, A. Al-bermani, and K. Lundqvist, "Evaluating the Effect of Arabic Engineering Students ' Learning Styles in Blended Programming Courses," J. Inf. Technol. Educ. Res., vol. 15, no. April, pp. 109-130, 2016.

[17] A. Al-azawei, P. Parslow, and K. Lundqvist, "Investigating the effect of learning styles in a blended e-learning system: An extension of the technology acceptance model ( TAM )," Australas. J. Educ. Technol., vol. 33, no. 2, pp. 1-23, 2017.

[18] S. N. M. Mohamad, "Model for Online Teaching Tools Based on Interpersonal, Visual and Verbal Intelligence," Universiti Teknikal Malaysia Melaka, 2014.

[19] A. Al-Azawei, P. Parslow, and K. Lundqvist, "Investigating the effect of learning styles in a blended e-learning system: An extension of the technology acceptance model (TAM)," Australas. J. Educ. Technol., vol. 33, no. 2, pp. 1-23, 2017.

[20] J. Rohaniyah, "Integrating Learning Style and Multiple Intelligences in Teaching and Learning Process," J. Pemikir. Penelit. Pendidik. dan Sains, vol. 5, no. 1, pp. 19-27, 2017.

[21] T. C. Hsu, S. C. Chang, and N. C. Liu, "Peer assessment of webpage design: Behavioral sequential analysis based on eye tracking evidence," Educ. Technol. Soc., vol. 21, no. 2, pp. 305-321, 2018.

[22] S. Mukherjee, "Learning Style of Humanities , Commerce and Science Students : A Study on Higher Secondary Students from West Bengal," Int. J. Indian Psychol., vol. 3, no. 3, pp. 15-22, 2016.

[23] L. D. Garner-O'Neale and S. Harrison, "An Investigation of the Learning styles and Study Habits of Chemistry Undergraduates in Barbados and their Effect as Predictors of Academic Achievement in Chemical Group Theory," J. Educ. Soc. Res., vol. 3, no. May, pp. 107122, 2013.

[24] M. Koc-Januchta, T. Hoffler, G.-B. Thoma, H. Prechtl, and D. Leutner, "Visualizers versus verbalizers: Effects of cognitive style on learning with texts and pictures - An eye-tracking study," Comput. Human Behav., vol. 68, pp. 170-179, 2017.

[25] Ancona, Kochan, Scully, V. Maanen, and Westney, "Managing For the Future," $1997 . \quad$ [Online]. Available: http://www.analytictech.com/mb021/cogquest.htm. [Accessed: 30-Apr2017].

[26] J. Simuth and I. Sarmany-Schuller, "Cognitive Style Variable in Elearning," in Procedia - Social and Behavioral Sciences, 2014, vol. 116, no. January 2013, pp. 1464-1467.

[27] D. Baneres, S. Caballé, and R. Clarisó, "Towards a Learning Analytics Support for Intelligent Tutoring Systems on MOOC Platforms," in Proceedings - 2016 10th International Conference on Complex, Intelligent, and Software Intensive Systems, CISIS 2016, 2016, no. October, pp. 103-110.

[28] W. F. Heinrich and J. E. Rivera, "A Framework for PLA in Traditional Higher Education: Experiential Learning Assessment for Embedded Outcomes," Prior Learning Assessment Inside Out, vol. 5, no. 5, pp. 1$5,2016$.

[29] J. W. Gikandi, D. Morrow, and N. E. Davis, "Online formative assessment in higher education: A review of the literature," Comput. Educ., vol. 57, no. 4, pp. 2333-2351, 2011. 
[30] Z. G. Baleni, "Online Formative Assessment in Higher Education: Its Pros and Cons.," Proc. Eur. Conf. e-Learning, vol. 13, no. 4, pp. 43-47, 2014.

[31] OECD, "Assessment For Learning - The Case for Formative Assessment," in OECD/CERI International Conference - Learning in the 21st Century: Research, Innovation and Policy, 2008, pp. 1-24.

[32] W. Admiraal, B. Huisman, and M. Van De Ven, "Self- and Peer Assessment in Massive Open Online Courses," Int. J. High. Educ., vol. 3, no. 3, pp. 119-128, 2014.

[33] H. P. Chan and I. King, "Leveraging Social Connections to Improve Peer Assessment in MOOCs.," WWW (Companion Vol., pp. 341-349, 2017.

[34] M. Bearman, P. Dawson, D. Boud, M. Hall, S. Bennett, E. Molloy, and G. Joughin, "Guide to the Assessment Design Decisions Framework," 2014.

[35] P. J. Muñoz-Merino, J. A. Ruipérez-Valiente, J. L. Sanz, and C. Delgado Kloos, "Assessment Activities in MOOCs," 2015.

[36] M. Taras, "Student self-assessment: Processes and consequences," Teach. High. Educ., vol. 15, no. 2, pp. 199-209, 2010.

[37] J.-J. Vie, F. Popineau, É. Bruillard, Y. Bourda, and Jill-Jênn, “A Review of Recent Advances in Adaptive Assessment," Learn. Anal. Fundam. Appl. Trends, vol. 94, pp. 113-142, 2017.

[38] V. N. Gohokar, "Adaptive , Cognitive and Innovative Tools \& Techniques for improving Learning Performance: A Case Study," in International Conference on MOOC, Innovation and Technology in Education (MITE), 2014, pp. 47-52.
[39] T. Kintakaningrum, "A Study Of Consequences On Individual And Group Learning Performance Using A Web-Based And Mobile Supported Learning Management System," Universiti Teknikal Malaysia Melaka. Malaysia, 2012.

[40] K. Karthigeyan and K. Nirmala, "Learning Style Preference of English Language Learners," Educ. Confab J., vol. 2, no. 1, pp. 134-140, 2013.

[41] A. E. Labib, J. H. Canós, and M. C. Penadés, "On the way to learning style models integration: a Learner's Characteristics Ontology," Comput. Human Behav., vol. 73, pp. 433-445, 2017.

[42] S. H. Zhong, Y. Li, Y. Liu, and Z. Wang, "A computational investigation of learning behaviors in MOOCs," in Computer Applications in Engineering Education, 2017, no. November 2016, pp. $1-13$.

[43] S. Graf, Kinshuk, and T. C. Liu, "Identifying learning styles in learning management systems by using indications from students' behaviour," in Proceedings - The 8th IEEE International Conference on Advanced Learning Technologies, ICALT 2008, 2008, pp. 482-486.

[44] P. R. Lowenthal and C. B. Hodges, "In search of quality: Using Quality Matters to analyze the quality of massive, open, online courses (MOOCs)," Int. Rev. Res. Open Distrib. Learn., vol. 16, no. 5, pp. 83$101,2015$.

[45] Z. Ghaedi and B. Jam, "Relationship between Learning Styles and Motivation for Higher Education in EFL Students," in Theory and Practice in Language Studies, 2014, vol. 4, no. 6, pp. 1232-1237.

[46] P. Tulsi, M. Poonia, and P. Anu, "Learning Styles of Engineering Students,” J. Eng. Educ. Transform., vol. 30, no. 2, pp. 44-49, 2016 